\title{
Combining Ability and Heterosis Analyses for Earliness and Yield Potential in some Bread Wheat Crosses under Optimum and Late Sowing \\ Aboshosha, A. A. M. ${ }^{1}$; H. E. Galal ${ }^{1}$ and A. A. Youssef ${ }^{2}$ \\ ${ }^{1}$ Department of Genetics ,Faculty of Agriculture ,Kafrelsheikh University, Egypt and* \\ ${ }^{2}$ Wheat research department, Field crop Research Institute, Agricultural Research Centre, Giza, Egypt.

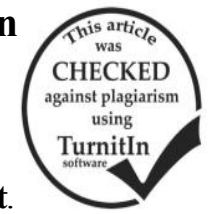

\section{ABSTRACT}

This study was carried out during the two successive seasons 2014/2015 and 2015/2016 at the experimental farm of Sakha Agricultural Research Station, Kafr El-Sheikh, Egypt. Eight bread wheat (Triticum aestivum L.) cultivars and lines, differing in their earliness were used as parents and evaluated with their $28 \mathrm{~F} 1$ 's under optimum $\left(29^{\text {th }}\right.$ Nov. $)$ and late $\left(29^{\text {th }}\right.$ Dec) sowing dates. The studied characters were earliness, grain yield and its components. significant differences were detected between the two sowing dates and among the studied genotypes in each sowing date and across the two sowing dates. The mean squares of GCA and SCA for most studied characters were significant or heighly significant under both sowing dates. Means of the parents and their crosses were decreased under late sowing date for all the studied characters. The early parents and most of their F1's had the desirable mean values for combining ability and heterosis effects for earliness characters. Moreover, the parents Giza 171, Misr 2 and Line 1 (late parents) were the best parents for mean performance and general combining ability (GCA) for grain yield and its components in most cases. Four crosses resulting from late and early parents under both sowing dates were the highest ones and could be used in advanced studies for earliness and grain yield potential. The GCA/SCA ratios were more than unity for most studied characters under both sowing dates.

Keywords: Wheat, Diallel, Earliness, Yield Potential, Combining ability, Heterosis.

\section{INTRODUCTION}

Bread wheat (Triticum aestivum L.) is the most important cereal crop in Egypt as well as in most countries of the world. Developing new early-maturing cultivars of bread wheat without losses in grain yield ability is a major objective of many wheat breeding program. Earliness in wheat seems to be affected by many characters related to the phonological development like growth and its components, and eventually reflect that on the grain yield (Menshawy, 2005). Early heading and maturity cultivars in wheat are advantageous in areas where temperature rises greatly during the grain filling phase (or late sowing); They also provide more options for farmer to adopt diverse crop pattern and potential drought escape mechanism (Mahar et al. 2003). In addition, early cultivars can be used in cotton-wheat double cropping systems in North Delta region (Menshawy, 2007). Wheat genotypes had great differences in their responses under different environments for the studied characters and delaying sowing date caused reduction in earliness traits, plant height, grain yield and yield components (El-Marakby et al., 2007). Combining ability studies are frequently used by plant breeders to evaluate newly developed genotypes for their parental usefulness to incorporate them in hybridization programme. Analysis of Griffing (1956) is widely used tool to classify lines in terms of their ability to be combined in hybrids (Aglan, 2009). For precise information, the combining ability should be assessed under multi environments likes sowing dates (Aglan, 2009). Significant desirable GCA and SCA were reported for earliness, grain yield and yield components (Abd El-Hamid, 2013; Aglan, 2013; Ram et al., 2014; Abdallah et al., 2015; Kaur and Mondal, 2016). Furthermore, general and specific combining abilities ratios were reported to be more than unity for earliness characters (Abd El-Hamid, 2013; Aglan, 2013; Ram et al, 2014; Abdallah, et al, 2015; Kaur and Mondal, 2016; El-Saadoown et al., 2017 and Jatav et al., 2017). In addition, Moshref (2006); and Salem and Abdel Dayem (2006) stated desirable significant heterosis for many characters in some bread wheat crosses.

Therefore, the objectives of the present investigation were to: (1) investigate eight diverse early maturing genotypes and their F1 crosses under optimum and late sowing dates condition, (2) determine the heterosis, combining ability estimates for earliness and agronomic characters, and (3) obtain promising early crosses with a relatively satisfactory grain yield.

\section{MATERIALS AND METHODS}

\section{A- The studied genotypes and layout}

This study was carried out during the two successive seasons 2014/2015 and 2015/2016 at the Experimental Farm of Sakha Agricultural Research Station, Kafr El-sheikh, Agricultural Research Center (ARC), Egypt. Eight bread wheat cultivars and lines, differing in their earliness time were used as parents. However, the names, pedigrees and earliness status of these parents are shown in Table (1).

Table 1. Genotypes names and selection history of the used bread wheat parents.

\begin{tabular}{|c|c|c|}
\hline Name & Selection history & $\begin{array}{l}\text { Earliness } \\
\text { for maturity }\end{array}$ \\
\hline Giza 171 & SAKHA 93 / GEMMEIZA 9 S.6-1GZ-4GZ-1GZ-2GZ-0S & Late \\
\hline Sids 12 & $\begin{array}{l}\mathrm{BUC} / / 7 \mathrm{C} / \mathrm{ALD} / 5 / \mathrm{MAY} \text { 74/ON//1160.147/3/BB/GLL/4/CHAT"S"/6/MAYA/VUL//CMH74 } \\
\text { A.630/4*SX SD7096-4SD-1SD-1SD-0SD }\end{array}$ & Late \\
\hline Misr 2 & SKAUZ / BAV92 CMSS96M03611S-1M-010SY-010M-010SY-8M-0Y-0S & late \\
\hline Line 1 & $\begin{array}{l}\text { KAUZ/PASTOR//PBW343 } \\
\text { CMSS00M02401S-030M-030WGY-030M-18M-0Y-0SH }\end{array}$ & late \\
\hline Line 2 & $\begin{array}{c}\text { GIZA } 164 \text { / SAKHA } 61 \text { // PLO / TR810328/6/ GIZA 168/5/ MAI "S" / PJ // ENU "S"/3/ KITO / POTO. } 19 \text { // } \\
\text { MO / JUP /4/ K } 134 \text { (60)/ VEE S. 16601 -032S -0SY-1S -0S }\end{array}$ & early \\
\hline Line 3 & $\begin{array}{l}\text { SAKHA } 94 \text { /5/ BL1133 /3/ CMH 79A.955*2/ CNO 79 // CMH 79A.955 / BOW"s" /4/ GIZA 164/ SAKHA 61 / } \\
6 \text { / SAKHA 12 /5/ KVZ // CNO } 67 \text { / PJ } 62 \text { /3/ YD "S" / BLO "S" /4/ K } 134 \text { (60)/ VEE S.12601-10S-4S-2S-0S }\end{array}$ & early \\
\hline Line 4 & $\begin{array}{c}\text { SAKHA } 12 \text { /5/ KVZ // CNO 67 / PJ 62 /3/ YD "S" / BLO "S" /4/ K 134 (60) / VEE } \\
\text { S.14665-4S-1S-0SY-0S }\end{array}$ & early \\
\hline Line 5 & Mutation Line- Sakha wheat breading program. & Early \\
\hline
\end{tabular}


All possible parental combinations excluding reciprocals were made among the eight genotypes to produce their F1 seeds in 2014/2015 season. In 2015/2016 the eight parents and their 28 F1's (36 entries) were evaluated under two natural photothermal environments created by adopting different dates of sowing i.e., $29^{\text {th }}$ Nov. (optimum) and $29^{\text {th }}$ Dec. 2014 (late). These 36 entries were repeated four times in a randomized complete block design (RCBD). Each replicate included 38 rows, the two outside rows of them were border. Each genotype was represented by a single row $4 \mathrm{~m}$ long, $30 \mathrm{~cm}$ apart and the plants were spaced $20 \mathrm{~cm}$ apart within the rows. All cultural practices were applied according to the recommendations of the ARC for the region. The meteorological data for the two winter growing seasons at Sakha Meteorological Station are given in Table 2 .

Table 2. Monthly mean of air temperature (AT OC), relative humidity (RH \%) and rainfed (mm/month) in winter season $2015 / 2016$ at Sakha site.

\begin{tabular}{lcccc}
\hline \multirow{2}{*}{ Month } & \multicolumn{2}{c}{ AT OC } & \multirow{2}{*}{ RH\% } & $\begin{array}{c}\text { Rainfed } \\
\text { (mm) }\end{array}$ \\
\cline { 2 - 5 } & Max.* & Min.** & & 17.40 \\
November & 22.5 & 11.50 & 72.80 & 15.00 \\
December & 16.6 & 7.36 & 76.40 & 5.11 \\
January & 15.8 & 5.61 & 74.50 & - \\
February & 22.2 & 9.61 & 65.50 & 4.50 \\
March & 21.3 & 14.62 & 67.80 & - \\
April & 27 & 18.60 & 65.00 & - \\
May & 26.9 & 20.90 & 85.00 & 10.5 \\
Mean & 21.75 & 12.60 & 72.24 & 10 \\
* Max = maximum temperature, ** Min = minimum temperature.
\end{tabular}

\section{B- The studied characters}

The studied characters were measured on five guarded plants randomly chosen per row in each replicate and classified into:

1- Earliness characters; number of days to heading (DH), number of days to maturity (DM), grain filling period (GFP, in days); equal to the number of days from heading to maturity, and grain filling rate (GFR) in mg plant ${ }^{-1}$ days-1; equal to grain yield (GY) divided by GFP.
2- Yield and its components characters and include: plant height $(\mathrm{Ph}, \mathrm{cm})$, number of spikes plant ${ }^{-1}(\mathrm{SP})$, number of kernels spike ${ }^{-1}$ (KS), 100-kernel weight $(\mathrm{KW}, \mathrm{g})$ and grain yield plant ${ }^{-1}(\mathrm{GY}, \mathrm{g}$.$) .$

$C$ - The statistical and biometrical analyses:

The data were analyzed on the mean of the five plants in each replication. The analysis of variance was calculated for each sowing date separately for the parents and their crosses according to Snedecor and Cochran (1980). Genotypes were divided to parents, crosses and parents vs. crosses. The LSD test at $5 \%$ and $1 \%$ according to Steel and Torrie (1980) was used to compare the mean performance of genotypes. The effects of genotypes were assumed to be fixed. GCA and SCA effects were calculated using Griffing (1956) method 2 model1. The GCA/SCA ratios were calculated according to Baker (1978). In addition, heterosis as proposed by Wynne et al (1970), was determined as the deviation of the F1 means from better parent mean and expressed as percentage. Furthermore, all statistical analysis was performed using the statistical routines available in Microsoft EXCEL (2016).

\section{RESULTS AND DISCUSSION}

\section{A- Analysis of variances \\ 1- Earliness characters}

Table 3 showed that significant $(0.01$ or 0.05 probability) mean squares were detected between the two sowing dates for genotypes, parents, crosses, and parents vs. crosses, except for parents vs. crosses for DM under late sowing date and GFP under optimum sowing date. These results are in the same trend with those reported by Menshawy (2005); Hammad and Abd El-Aty (2007) and Moussa and Morad (2009). It could be concluded that most source of variations were higher at optimum sowing date, compared with those obtained from late sowing date. These results indicate that selection for earliness was predicted to be more effective under optimum sowing date.

Table 3. Analysis of variance under optimum (SD1) and late (SD2) sowing dates for DH, DM, GFP and GFR

\begin{tabular}{|c|c|c|c|c|c|c|c|c|c|}
\hline \multirow[t]{2}{*}{ S. O. V } & \multirow{2}{*}{$\begin{array}{c}\text { d.f } \\
\text { Sowing date }\end{array}$} & \multicolumn{2}{|c|}{$\begin{array}{l}\text { Days to heading } \\
\text { (day) }\end{array}$} & \multicolumn{2}{|c|}{$\begin{array}{l}\text { Days to maturity } \\
\text { (day) }\end{array}$} & \multicolumn{2}{|c|}{$\begin{array}{l}\text { Grain filling } \\
\text { period (day) }\end{array}$} & \multicolumn{2}{|c|}{$\begin{array}{l}\text { Grain filling rate } \\
\left.\text { (g plant }^{-1} \text { day }^{-1}\right)\end{array}$} \\
\hline & & SD1 & SD2 & SD1 & SD2 & SD1 & SD2 & SD1 & SD2 \\
\hline Replication (Rep) & 3 & 0.5 & $4.6^{* *}$ & 0.1 & 1.5 & 0.9 & $6.3^{* *}$ & $0.01 * *$ & $0.01 *$ \\
\hline Genotypes $(\mathrm{G})$ & 35 & $150.6 * *$ & $78.8 * *$ & $85.1 * *$ & $31.4 * *$ & $20.9 * *$ & $19.6^{* *}$ & $0.2 * *$ & $0.1 * *$ \\
\hline Parents (P) & 7 & $301.9 * *$ & $191.7 * *$ & $217.9 * *$ & $77.7 * *$ & $27.5 * *$ & $46.1 * *$ & $0.3 * *$ & $0.1 * *$ \\
\hline Crosses (C) & 27 & $116.6 * *$ & $52.2 * *$ & $53.8 * *$ & $20.5 * *$ & $19.9 * *$ & $13.3 * *$ & $0.1 * *$ & $0.1 * *$ \\
\hline $\mathrm{P}$ vs. C & 1 & $7.6 * *$ & $7.5^{* *}$ & $1.9 *$ & 0.1 & 1.9 & $5.9 * *$ & $0.03 * *$ & $0.2 * *$ \\
\hline Error & 105 & 0.7 & 0.5 & 0.3 & 0.7 & 0.8 & 0.8 & 0 & 0 \\
\hline
\end{tabular}

$*$ and $*$ significant at 0.05 and 0.01 levels of probability, respectively.

\section{2- Agronomic characters}

All sources of variations (Table 4) for plant height and yield and yield components had Significant ( 0.01 or 0.05 probability) values of mean squares, except for parents vs. crosses for KS under optimum sowing date. These results reflect the variability between the two sowing dates and among the studied genotypes in each sowing date and that the behavior of each genotype was markedly differed from sowing date to another and the presence of the heterotic effect.

The most source of variations for plant height as well as yield and its components were higher at optimum sowing date compared with those obtained from the late sowing date. Therefore, the selection for agronomic characters was predicted to be more effective under optimum sowing date. These results are in harmony with those obtained by Menshawy et al. (2004); Mousa (2005); and Moussa and morad (2009).

\section{B- Mean Performance}

\section{1- Earliness characters}

From the wheat breeder view, the low values of $\mathrm{DH}$ and DM are desirable. Mean values (Table 5) of the parents and crosses were decreased under late sowing for $\mathrm{DH}, \mathrm{DM}$, GFP and GFR. This trend was true for all parents and 
crosses. It may be due to the genotype differentiations response and sensitivity to temperature and light changes when plants are exposing to different degrees of temperature and light day requirements through late sowing dates, which will be certainly reflected on phases of development and the transformation from vegetative phase to reproductive one. Similar results were obtained by Menshawy (2007); Aglan (2009) and Abdallah, et al. (2015).

Table 4. Analysis of variance under optimum (SD1), late (SD2) sowing dates for plant height and grain yield plant $^{-1}$ and yield components.

\begin{tabular}{|c|c|c|c|c|c|c|c|c|c|c|c|}
\hline \multirow[t]{2}{*}{ S. O. V } & \multirow{2}{*}{$\begin{array}{c}\text { d.f } \\
\text { Sowing date }\end{array}$} & \multicolumn{2}{|c|}{$\begin{array}{c}\text { Plant height } \\
\text { (Ph) }\end{array}$} & \multicolumn{2}{|c|}{$\begin{array}{l}\text { No. of spikes } \\
\text { plant }^{-1} \text { (SP) }\end{array}$} & \multicolumn{2}{|c|}{$\begin{array}{c}\text { No. of kernels } \\
\text { spike }^{-1}(\mathrm{KS})\end{array}$} & \multicolumn{2}{|c|}{$\begin{array}{c}100 \text { kernel } \\
\text { weight }(\mathrm{KW})\end{array}$} & \multicolumn{2}{|c|}{$\begin{array}{c}\text { Grain yield } \\
\text { plant }^{-1}(\text { GY/P) }\end{array}$} \\
\hline & & SD1 & SD2 & SD1 & SD2 & SD1 & SD2 & SD1 & SD2 & SD1 & SD2 \\
\hline Replication (Rep) & 3 & $39.7 * *$ & 9.7 & $32.8^{* *}$ & 1.2 & 24.9 & $34.3 *$ & $0.2 * *$ & 0.1 & $16.0 * *$ & 4.8 \\
\hline & 35 & $127.5 * *$ & $127.7 * *$ & $70.6 * *$ & $41.7^{* *}$ & $822.0 * *$ & & $0.8 * *$ & & $309.4 * *$ & $100.9 * *$ \\
\hline & 7 & $273.5 * *$ & $250.1 * *$ & $155.0 * *$ & $82.9^{* *}$ & $1019.2 * *$ & & $1.1 * *$ & & 663. & $130.2 * *$ \\
\hline $\mathrm{Crc}$ & 27 & $87.8^{* *}$ & $90.6^{* *}$ & $50.3^{* *}$ & $32.0 * *$ & $799.9 * *$ & $535.9^{* *}$ & $0.6^{* *}$ & & $225.7 * *$ & $82.1 * *$ \\
\hline & 1 & $176.0 * *$ & $273.8 * *$ & $27.5 * *$ & $13.2 * *$ & 38.9 & $72.2 *$ & $4.3 * *$ & $4.0 * *$ & $89.6 * *$ & $403.6 * *$ \\
\hline Error & 105 & 7.1 & 6.3 & 2.3 & 1.5 & 14.9 & 11.7 & 0.03 & 0.02 & 3.3 & 2.6 \\
\hline
\end{tabular}

Table 5. Mean performance of the parents and their F1 crosses for earliness characters under optimum (SD1) and late (SD2) sowing dates.

\begin{tabular}{|c|c|c|c|c|c|c|c|c|}
\hline \multirow{2}{*}{ Genotypes } & \multicolumn{2}{|c|}{ Days to heading (day) } & \multicolumn{2}{|c|}{ Days to maturity (day) } & \multicolumn{2}{|c|}{ Grain filling period (day) } & \multicolumn{2}{|c|}{ Grain filling rate $\left(\mathrm{g} \mathrm{plant}^{-1} \mathrm{day}^{-1}\right)$} \\
\hline & SD1 & SD2 & SD1 & SD2 & SD1 & SD2 & SD1 & SD2 \\
\hline Giza 171 & 93 & 85 & 144 & 126 & 51 & 41 & 1.29 & 0.84 \\
\hline Sids 12 & 88 & 82 & 142 & 124 & 54 & 42 & 0.75 & 0.57 \\
\hline Misr 2 & 99 & 85 & 149 & 130 & 50 & 45 & 1.06 & 0.78 \\
\hline Line 1 & 102 & 90 & 150 & 127 & 49 & 38 & 1.10 & 0.84 \\
\hline Line 2 & 81 & 72 & 131 & 119 & 51 & 47 & 0.70 & 0.56 \\
\hline Line 3 & 82 & 73 & 133 & 120 & 52 & 47 & 0.58 & 0.43 \\
\hline Line 4 & 83 & 76 & 134 & 119 & 51 & 43 & 0.65 & 0.57 \\
\hline Line 5 & 80 & 72 & 136 & 119 & 57 & 47 & 0.57 & 0.48 \\
\hline Mean of parents & 88 & 79 & 140 & 123 & 52 & 44 & 0.84 & 0.63 \\
\hline Giza $171 \times$ Sids 12 & 92 & 82 & 143 & 125 & 52 & 43 & 0.85 & 0.73 \\
\hline Giza $171 \times$ Misr 2 & 97 & 85 & 145 & 129 & 48 & 44 & 1.05 & 0.91 \\
\hline Giza $171 \times$ Line 1 & 98 & 85 & 144 & 127 & 47 & 42 & 1.03 & 0.99 \\
\hline Giza $171 \times$ Line 2 & 88 & 78 & 138 & 123 & 50 & 45 & 0.93 & 0.69 \\
\hline Giza $171 \times$ Line 3 & 87 & 78 & 141 & 123 & 54 & 45 & 0.84 & 0.67 \\
\hline Giza $171 \times$ Line 4 & 90 & 79 & 141 & 122 & 51 & 44 & 0.97 & 0.77 \\
\hline Giza $171 \times$ Line 5 & 90 & 79 & 140 & 123 & 51 & 43 & 0.65 & 0.66 \\
\hline Sids $12 \times$ Misr 2 & 96 & 83 & 144 & 126 & 48 & 43 & 1.13 & 0.74 \\
\hline Sids $12 \times$ Line 1 & 97 & 83 & 146 & 125 & 49 & 42 & 0.76 & 0.72 \\
\hline Sids $12 \times$ Line 2 & 85 & 75 & 138 & 123 & 53 & 48 & 0.69 & 0.59 \\
\hline Sids $12 \times$ Line 3 & 84 & 76 & 139 & 122 & 55 & 46 & 0.75 & 0.80 \\
\hline Sids $12 \times$ Line 4 & 88 & 78 & 139 & 122 & 51 & 44 & 0.87 & 0.67 \\
\hline Sids $12 \times$ Line 5 & 84 & 76 & 138 & 122 & 54 & 46 & 0.56 & 0.57 \\
\hline Misr $2 \times$ Line 1 & 99 & 86 & 148 & 125 & 49 & 39 & 1.17 & 0.91 \\
\hline Misr $2 \times$ Line 2 & 89 & 79 & 140 & 123 & 51 & 45 & 0.92 & 0.79 \\
\hline Misr $2 \times$ Line 3 & 89 & 78 & 142 & 123 & 53 & 45 & 0.81 & 0.85 \\
\hline Misr $2 \times$ Line 4 & 93 & 80 & 142 & 125 & 48 & 44 & 0.90 & 0.79 \\
\hline Misr $2 \times$ Line 5 & 90 & 80 & 141 & 123 & 51 & 43 & 0.75 & 0.75 \\
\hline Line $1 \times$ Line 2 & 89 & 79 & 140 & 122 & 50 & 43 & 0.80 & 0.71 \\
\hline Line $1 \times$ Line 3 & 90 & 79 & 142 & 123 & 53 & 44 & 0.74 & 0.74 \\
\hline Line $1 \times$ Line 4 & 93 & 82 & 142 & 124 & 49 & 42 & 0.84 & 0.75 \\
\hline Line $1 \times$ Line 5 & 90 & 79 & 142 & 123 & 51 & 44 & 0.81 & 0.77 \\
\hline Line $2 \times$ Line 3 & 82 & 73 & 134 & 119 & 52 & 46 & 0.65 & 0.52 \\
\hline Line $2 \times$ Line 4 & 82 & 75 & 135 & 120 & 54 & 45 & 0.64 & 0.64 \\
\hline Line $2 \times$ Line 5 & 80 & 72 & 134 & 119 & 54 & 47 & 0.58 & 0.59 \\
\hline Line $3 \times$ Line 4 & 84 & 75 & 136 & 121 & 52 & 46 & 0.73 & 0.55 \\
\hline Line $3 \times$ Line 5 & 82 & 74 & 136 & 121 & 54 & 47 & 0.50 & 0.53 \\
\hline Line $4 \times$ Line 5 & 83 & 75 & 136 & 120 & 53 & 45 & 0.58 & 0.58 \\
\hline Mean of F1 & 89 & 79 & 140 & 123 & 51 & 44 & 0.80 & 0.71 \\
\hline Over all mean & 89 & 79 & 140 & 123 & 51 & 44 & 0.81 & 0.70 \\
\hline LSD 0.05 & 1.2 & 0.9 & 0.8 & 1.2 & 1.3 & 1.2 & 0.05 & 0.05 \\
\hline LSD 0.01 & 1.6 & 1.3 & 1 & 1.5 & 1.7 & 1.6 & 0.07 & 0.07 \\
\hline
\end{tabular}

Regarding parents, the days to heading ranged from 80 days for Line 5 to 102 days for Linel and from 72 days for Line 2 and Line 5 to 90 days for Line 1 under optimum and late sowing dates, respectively. The days to maturity ranged between 131 days for Line 2 to 150 days for Line1 and from 119 days for Lines 2, 4 and 5 to 130 days for
Misr 2 under optimum and late sowing dates, sequently. Values of grain filling period ranged from 49 days for Line1 to 57 days for Line5 and from 38 days for Line1 to 47 days for Lines 2, 3 and 5 under optimum and late sowing dates, consecutively. Grain filling rates differed from $0.5 \mathrm{~g}$ for Line 5 to $1.29 \mathrm{~g}$ for Giza 171 and from $0.43 \mathrm{~g}$ 
for Line3 to $0.84 \mathrm{~g}$ for Giza 171 and Line1 under optimum, and late sowing dates, in sequence.

At the level of crosses, the days to heading ranged between 80 days for Line $2 \mathrm{x}$ Line 5 to 99 days for Misr $2 \mathrm{x}$ Line 1 and from 72 days for Line $2 \times$ Line 5 to 86 days for Misr 2 x Line 1 under optimum and late sowing dates, respectively. The days to maturity were between 134 days for Line 2 x Line 3 and Line 2 x Line 5 to 148 days for Misr $2 \times$ Line 1 and from 119 days for Line $2 \times$ Line 3 and Line 2 $\mathrm{x}$ Line 5 to 129 days for Giza 171 x Misr 2 under optimum and late sowing dates, in sequence. Values of grain filling period were ranged from 47 days for Giza $171 \times$ Line 1 to 54.9 days for Sids $12 \mathrm{x}$ Line 3 and from 39 days for Misr $2 \mathrm{x}$ Line 1 to 48 days for Sids $12 \times$ Line 2 under optimum and late sowing dates, sequently. Grain filling rates differed from $0.50 \mathrm{~g}$ for Line4 $\mathrm{x}$ Line5 to $1.17 \mathrm{~g}$ for Misr $2 \mathrm{x}$ Line 1 and from $0.52 \mathrm{~g}$ for Line $2 \mathrm{x}$ Line 3 to $0.99 \mathrm{~g}$ for Giza $171 \mathrm{x}$ Line 1 under optimum and late sowing dates, consecutively.

In general, the early parents were Lines 2, 3, 4, and 5 respectively and the moderate late parents were Sids 12 and Giza 171. Moreover, most of their resulted crosses gave the most superior and desirable values toward earliness, indicating that these genotypes could be used to obtain early wheat cultivars. These results are in accordance with Menshawy (2005) and Aglan (2009). 2- Agronomic characters

The means of plant height, grain yield plant $^{-1}$ and yield components for the parents, crosses and all genotypes are illustrated in Tables 6. Data in this Table indicated that all values decreased significantly in the late sowing. This was true for the means of all genotypes. Similar trend was observed by Menshawy (2007), and Abdallah, et al. (2015).

Table 6. Mean performance of the parents and their $F 1$ crosses for the agronomic characters under optimum (SD1) and late (SD2) sowing dates.

\begin{tabular}{|c|c|c|c|c|c|c|c|c|c|c|}
\hline \multirow[t]{2}{*}{ Genotypes } & \multicolumn{2}{|c|}{$\begin{array}{l}\text { Plant height } \\
\text { (cm) (Ph) }\end{array}$} & \multicolumn{2}{|c|}{$\begin{array}{l}\text { No. of spikes } \\
\text { plant }^{-1} \text { (SP) }\end{array}$} & \multicolumn{2}{|c|}{$\begin{array}{l}\text { No. of kernels } \\
\text { spike }^{-1}(\mathrm{KS})\end{array}$} & \multicolumn{2}{|c|}{$\begin{array}{c}\text { 100-kernel } \\
\text { weight }(g)(\mathrm{KW})\end{array}$} & \multicolumn{2}{|c|}{$\begin{array}{c}\text { Grain yield } \\
\text { plant }^{-1}(\mathrm{~g})(\mathrm{GY} / \mathrm{P})\end{array}$} \\
\hline & SD1 & SD2 & SD1 & SD2 & SD1 & SD2 & SD1 & SD2 & SD1 & SD2 \\
\hline$\overline{\text { Giza } 171}$ & 113 & 101 & 24 & 18 & 91 & 70 & 5.14 & 4.54 & 65.8 & 34.6 \\
\hline Sids 12 & 100 & 93 & 9 & 8 & 117 & 95 & 5.15 & 4.10 & 40.2 & 23.9 \\
\hline Misr 2 & 113 & 106 & 29 & 24 & 92 & 86 & 4.11 & 3.80 & 52.4 & 35.3 \\
\hline Line 1 & 90 & 84 & 23 & 19 & 83 & 70 & 4.35 & 4.13 & 53.3 & 31.7 \\
\hline Line 2 & 96 & 88 & 19 & 18 & 75 & 59 & 3.86 & 3.66 & 35.6 & 26.2 \\
\hline Line 3 & 98 & 89 & 16 & 14 & 73 & 55 & 4.03 & 3.84 & 30.0 & 20.5 \\
\hline Line 4 & 105 & 96 & 20 & 17 & 68 & 55 & 5.03 & 4.70 & 32.7 & 24.6 \\
\hline Line 5 & 95 & 86 & 15 & 13 & 75 & 56 & 4.74 & 4.56 & 32.5 & 22.4 \\
\hline Mean of parents & 101 & 93 & 19 & 16 & 84 & 68 & 4.55 & 4.17 & 42.8 & 27.4 \\
\hline Giza $171 \times$ Sids 12 & 103 & 99 & 15 & 13 & 113 & 89 & 5.02 & 4.49 & 43.9 & 30.9 \\
\hline Giza $171 \times$ Misr 2 & 103 & 96 & 20 & 18 & 84 & 76 & 4.99 & 4.81 & 48.3 & 41.0 \\
\hline Giza $171 \times$ Line 1 & 104 & 100 & 20 & 15 & 79 & 66 & 5.15 & 4.68 & 46.9 & 30.7 \\
\hline Giza $171 \times$ Line 2 & 100 & 93 & 21 & 16 & 81 & 64 & 4.85 & 4.62 & 45.7 & 30.1 \\
\hline Giza $171 \times$ Line 3 & 107 & 101 & 20 & 16 & 78 & 66 & 5.33 & 4.80 & 49.3 & 33.9 \\
\hline Giza $171 \times$ Line 4 & 106 & 100 & 18 & 15 & 75 & 60 & 5.57 & 4.92 & 33.0 & 28.5 \\
\hline Giza $171 \times$ Line 5 & 110 & 100 & 21 & 14 & 101 & 93 & 4.20 & 3.90 & 54.5 & 32.2 \\
\hline Sids $12 \times$ Misr 2 & 98 & 89 & 14 & 12 & 93 & 81 & 4.44 & 4.21 & 37.4 & 30.4 \\
\hline Sids $12 \times$ Line 1 & 96 & 92 & 9 & 8 & 110 & 88 & 5.39 & 4.79 & 36.5 & 28.1 \\
\hline Sids $12 \times$ Line 2 & 101 & 95 & 17 & 15 & 101 & 72 & 4.52 & 4.37 & 40.9 & 36.4 \\
\hline Sids $12 \times$ Line 3 & 106 & 95 & 13 & 11 & 107 & 85 & 4.97 & 4.72 & 44.7 & 29.4 \\
\hline Sids $12 \times$ Line 4 & 104 & 98 & 10 & 9 & 92 & 75 & 5.46 & 4.94 & 30.4 & 26.4 \\
\hline Sids $12 \times$ Line 5 & 108 & 103 & 22 & 17 & 89 & 83 & 4.40 & 4.35 & 57.3 & 35.3 \\
\hline Misr $2 \times$ Line 1 & 105 & 101 & 25 & 20 & 89 & 73 & 4.55 & 4.25 & 47.2 & 35.4 \\
\hline Misr $2 \times$ Line 2 & 111 & 100 & 19 & 18 & 82 & 74 & 4.50 & 4.13 & 42.5 & 38.2 \\
\hline Misr $2 \times$ Line 3 & 114 & 104 & 21 & 18 & 77 & 69 & 5.15 & 4.48 & 43.2 & 34.9 \\
\hline Misr $2 \times$ Line 4 & 108 & 99 & 21 & 17 & 78 & 64 & 4.99 & 4.73 & 38.1 & 32.2 \\
\hline Misr $2 \times$ Line 5 & 102 & 90 & 20 & 17 & 75 & 64 & 4.78 & 4.53 & 40.3 & 30.8 \\
\hline Line $1 \times$ Line 2 & 111 & 104 & 23 & 20 & 94 & 84 & 4.66 & 4.47 & 50.3 & 40.6 \\
\hline Line $1 \times$ Line 3 & 98 & 94 & 20 & 18 & 80 & 64 & 4.98 & 4.51 & 38.9 & 32.7 \\
\hline Line $1 \times$ Line 4 & 104 & 96 & 19 & 15 & 76 & 69 & 5.16 & 4.83 & 40.7 & 31.4 \\
\hline Line $1 \times$ Line 5 & 103 & 93 & 19 & 18 & 73 & 64 & 5.15 & 4.62 & 41.5 & 34.2 \\
\hline Line $2 \times$ Line 3 & 99 & 90 & 18 & 15 & 69 & 59 & 4.75 & 4.44 & 33.7 & 23.9 \\
\hline Line $2 \times$ Line 4 & 101 & 92 & 18 & 17 & 67 & 60 & 5.07 & 4.83 & 34.2 & 28.9 \\
\hline Line $2 \times$ Line 5 & 100 & 94 & 17 & 16 & 58 & 52 & 5.22 & 4.58 & 31.2 & 27.3 \\
\hline Line $3 \times$ Line 4 & 106 & 95 & 17 & 15 & 69 & 55 & 5.04 & 4.36 & 37.8 & 25.0 \\
\hline Line $3 \times$ Line 5 & 94 & 85 & 15 & 14 & 73 & 57 & 4.78 & 4.26 & 26.6 & 24.7 \\
\hline Line $4 \times$ Line 5 & 104 & 95 & 18 & 17 & 62 & 52 & 5.89 & 5.35 & 30.7 & 26.1 \\
\hline Mean of F1 & 104 & 96 & 18 & 16 & 83 & 70 & 4.96 & 4.57 & 40.9 & 31.4 \\
\hline Over all mean & 103 & 95 & 18 & 16 & 83 & 70 & 4.87 & 4.48 & 41.3 & 30.5 \\
\hline LSD 0.05 & 4 & 4 & 2 & 2 & 5.4 & 4.8 & .29 & .27 & 2.6 & 2.3 \\
\hline LSD 0.01 & 5 & 5 & 3 & 2 & 7.2 & 6.4 & .39 & .35 & 3.4 & 3.0 \\
\hline
\end{tabular}

With respect to parents, the plant height estimates (cm) ranged from $90 \mathrm{~cm}$ for Line 1 to $112.5 \mathrm{~cm}$ for Giza 171 and Misr2 and from $84 \mathrm{~cm}$ for Linel to $106 \mathrm{~cm}$ for Misr 2 under optimum and late sowing dates, respectively.
The minimum and maximum number of spikes plant $^{-1}$ were detected in Sids 12 and Misr 2 and were 9 and 29 as well as 8 and 24 under optimum and late sowing dates, sequently. Moreover, the minimum and maximum number 
of kernels spikes ${ }^{-1}$ were detected in Line 4 and Sids 12 and were 72 and 128 as well as 56 and 96 under optimum and late sowing dates, consecutively. Furthermore, values of 100-kernel weight $(\mathrm{g})$ ranged from $3.86 \mathrm{~g}$ for Line2 to 5.15 $\mathrm{g}$ for sids 12 and from $3.66 \mathrm{~g}$ for Line 2 to $4.70 \mathrm{~g}$ for Line 4 under optimum and late sowing dates, in sequence. In addition, values of grain yield plant ${ }^{-1}(\mathrm{~g})$ ranged from $30 \mathrm{~g}$ for Line 3 to $65.8 \mathrm{~g}$ for Giza 171 and from $20.5 \mathrm{~g}$ for Line3 to $35.3 \mathrm{~g}$ for Misr 2 under optimum and late sowing dates, respectively.

The superiority of Giza 171 in respect to grain yield plant $^{-1}$ ( $65.8 \mathrm{~g}$ ) may due to the highest number of spikes plant $^{-1}$ ( 24 ), kernel spike ${ }^{-1}$ ( 91 ) and weight of 100 kernel (5.14g) under the optimum sowing date. In addition, the highest grain yield plant $^{-1}$ (35.3 g) in Misr2 under the late sowing date may due to the highest number of spikes plant ${ }^{-1}$ ( 24 ) and kernel spike ${ }^{-1}$ ( 86 ).

Concerning crosses, the plant height estimates $(\mathrm{cm})$ ranged from $94 \mathrm{~cm}$ for Line $3 \mathrm{x}$ Line 5 to $114 \mathrm{~cm}$ for Misr $2 \mathrm{x}$ Line 3 and from $85 \mathrm{~cm}$ for Line 3 x Line 5 to $104 \mathrm{~cm}$ for Misr2 $\mathrm{x}$ Line3 and Line1 $\mathrm{x}$ Line2 under optimum and late sowing dates, respectively. Moreover, values of number of spikes plant $^{-1}$ ranged from 9 for Sids 12 x Line1 to 25 for Misr $2 \times$ Line1 and from 8 for Sids 12 x Linel to 20 for Misr 2 x Line1 and Line1 $x$ Line 2 under optimum and late sowing dates, in sequence. Additionally, the number of kernel spikes ${ }^{-1}$ ranged from 58 for Line 2 x Line5 to 113 for Giza171 x Sids12 and from 52 for Line $2 \times$ Line 5 and Line $4 \times$ Line5 to 93 for Giza171 x Line5 under optimum and late sowing dates, consecutively. Furthermore, values of 100 kernel weight (g) ranged from 4.20g for Giza171 x Line5 to 5.89g for Line4 $\mathrm{x}$ Line 5 and from 3.90 for Giza171 x Line 5 to 5.35 for Line $4 x$ Line5 under optimum and late sowing dates sequently. In addition, values of grain yield plant ${ }^{-1}(\mathrm{~g})$ ranged from $26.6 \mathrm{~g}$ for Line3 $x$ Line5 to $57.3 \mathrm{~g}$ for Sids12 $\mathrm{x}$ Line5 and from 24.7g for Line3 x Line5 to 41g for Giza171 x Misr2 under optimum and late sowing dates, respectively.

The mean performance of each $\mathrm{F} 1$ crosses different from the mean performance of the corresponding parent, subsequently the performance of cross combinations did not usually follow the performance of its parents involved in respect to grain yield and its components. It could be observed that the rang of crosses were larger than that of the parents in most cases of yield attributes, indicating the great variability among the crosses.

\section{C- Combining ability \\ 1- Analysis of variance}

Data presented in Table 7 revealed heighly significant general (GCA) and specific (SCA) combining ability mean squares for all studied characters under both optimum and late sowing dates.

Table 7. Mean squares for general (GCA) and specific (SCA) combining ability and GCA/SCA ratio for all studied characters under optimum (SD1) and late (SD2) sowing dates.

\begin{tabular}{|c|c|c|c|c|c|c|}
\hline Character & & Genotypes (G) & GCA & SCA & Error & GCA/ SCA ratio \\
\hline$\overline{\mathrm{df}}$ & Sowing date & 35 & 7 & 28 & 105 & \\
\hline \multirow{2}{*}{ Days to heading } & SD1 & $150.6 * *$ & $732.8 * *$ & $5.0 * *$ & 0.7 & 17.1 \\
\hline & SD2 & $78.8 * *$ & $380.0 * *$ & $3.5 * *$ & 0.5 & 12.3 \\
\hline \multirow{2}{*}{ Days to maturity } & SD1 & $85.1 * *$ & $408.5^{* *}$ & $4.3 * *$ & 0.3 & 10.3 \\
\hline & SD2 & $31.4 * *$ & $143.9^{* *}$ & $3.2 * *$ & 0.7 & 5.7 \\
\hline \multirow{2}{*}{ Grain filling period } & SD1 & $20.9 * *$ & $71.3 * *$ & $8.4 * *$ & 0.8 & 0.9 \\
\hline & SD2 & $19.6 * *$ & $77.3 * *$ & $5.2 * *$ & 0.8 & 1.7 \\
\hline \multirow{2}{*}{ Grain filling rate } & SD1 & $0.2 * *$ & $0.6^{* *}$ & $0.03 * *$ & 0.001 & 2.2 \\
\hline & SD2 & $0.1 * *$ & $0.3 * *$ & $0.02 * *$ & 0.001 & 1.5 \\
\hline \multirow{2}{*}{ Plant height } & SD1 & $127.5 * *$ & $489.5^{* *}$ & $37.0 * *$ & 7 & 1.6 \\
\hline & SD2 & $127.7 * *$ & $487.7 * *$ & $37.8 * *$ & 6.3 & 1.5 \\
\hline \multirow{2}{*}{ No. of spikes plant ${ }^{-1}$} & SD1 & $70.6 * *$ & $294.9 * *$ & $14.5 * *$ & 2.3 & 2.4 \\
\hline & SD2 & $41.7 * *$ & $167.6 * *$ & $10.2 * *$ & 1.5 & 1.9 \\
\hline \multirow{2}{*}{ No. of kernels spike ${ }^{-1}$} & SD1 & $822.0 * *$ & $3614.6^{* *}$ & $123.9^{* *}$ & 14.9 & 3.3 \\
\hline & SD2 & $602.4 * *$ & $2797.1 * *$ & $53.7 * *$ & 11.7 & 6.6 \\
\hline \multirow{2}{*}{100 - kernel weight } & SD1 & $0.8 * *$ & $2.2 * *$ & $0.5^{* *}$ & 0.001 & 0.5 \\
\hline & SD2 & $0.5^{* *}$ & $1.4 * *$ & $0.3 * *$ & 0.001 & 0.5 \\
\hline \multirow{2}{*}{ Grain yield plant ${ }^{-1}$} & SD1 & $309.4 * *$ & $1214.9 * *$ & $83.0 * *$ & 3.3 & 1.5 \\
\hline & SD2 & $100.9 * *$ & $325.7 * *$ & $44.7 * *$ & 2.6 & 0.8 \\
\hline
\end{tabular}

* and ** significant at 0.05 and 0.01 levels of probability, respectively.

These results indicate the importance role of additive and non-additive effects in determining the performance of these characters. Moreover, the selection of these traits would not be effective in a single condition but more conditions would be required. In this respect, Naseem et al. (2015), Abdallah, et al. (2015), Hei et al. (2016), Kaur and Mondal (2016), El-Saadoown et al (2017), Jatav et al. (2017)

Nevertheless, GCA variance values were higher than SCA for all characters under these study at the two sowing dates, proving that, selection for improve the studied characters would be more effective using some of the present parents and crosses. In addition, the ratios of GCA/SCA under the two sowing dates were more than unity for all characters, except for GFP under optimum sowing date, KW under both conditions and GY under late sowing date, meaning that additive gene effects predominantly control these characters. Therefore, it could be concluded that selection procedures based on the accumulation of additive effects would be more effective in early segregated generations. Similar results were obtained by Abdallah, et al, (2015), Kaur and Mondal (2016), El-Saadoown et al., (2017) and Jatav et al., (2017) reported significant mean squares of general and specific combining ability for earliness and agronomic characters.

\section{2- General combining ability (GCA) effects}

Wheat breeders are interested to get significant negative GCA for days to heading, and maturity and plant height, and significant positive effects for grain filling period and rate and grain yield and its components. 
a- Earliness characters

Table 8 illustrate that Line 2 , Line 3 , Line 4 and Line 5 had significant negative GCA effects and so were the best combiners for days to heading and maturity under both conditions.

In addition, Giza 171, Misr 2 and Line 1 had significant negative GCA and were the best combiners for grain filling period. Also, Giza 171, Misr 2 and Line 1 were the best combiners for grain filling rate under both conditions base on their significant or highly significant positive GCA. It was interested to notice the strong relationship between GCA effect values and their corresponding mean performances, where early mature parents had the lowest mean performances and negative sign of GCA effects for most earliness components. These results were agreed with those reported by Aglan (2009)

Table 8. Estimates of general combining ability effects of the parents for days to heading and maturity and grain filling period and rate under optimum (SD1) and late (SD2) sowing dates.

\begin{tabular}{lcccccccc}
\hline \multirow{2}{*}{ Parents } & \multicolumn{2}{c}{ Days to heading (day) } & Days to maturity (day) & \multicolumn{2}{c}{ Grain filling period(day) } & \multicolumn{2}{c}{ Grain filling rate $\left(\right.$ g plant $^{-1}$ day $^{-1}$ ) } \\
\cline { 2 - 8 } & SD1 & SD2 & SD1 & SD2 & SD1 & SD2 & SD1 & SD2 \\
\hline Giza 171 & $2.83^{* *}$ & $2.74^{* *}$ & $2.07^{* *}$ & $1.77^{* *}$ & $-0.76^{* *}$ & $-0.97^{* *}$ & $0.16^{* *}$ & $0.08^{* *}$ \\
Sids 12 & 0.24 & $0.75^{* *}$ & $1.04^{* *}$ & $0.57^{* *}$ & $0.8^{* *}$ & -0.18 & $-0.02^{* *}$ & $-0.03^{* *}$ \\
Misr 2 & $5.29^{* *}$ & $3.09^{* *}$ & $3.76^{* *}$ & $2.76^{* *}$ & $-1.53^{* *}$ & $-0.33^{*}$ & $0.15^{* *}$ & $0.1^{* *}$ \\
Line 1 & $6.06^{* *}$ & $4.14^{* *}$ & $4.32^{* *}$ & $1.58^{* *}$ & $-1.74^{* *}$ & $-2.56^{* *}$ & $0.11^{* *}$ & $0.1^{* *}$ \\
Line 2 & $-4.4^{* *}$ & $-3.49^{* *}$ & $-4.02^{* *}$ & $-2.09^{* *}$ & $0.37^{* *}$ & $1.4^{* *}$ & $-0.07^{* *}$ & $-0.06^{* *}$ \\
Line 3 & $-3.88^{* *}$ & $-2.97^{* *}$ & $-2.53^{* *}$ & $-1.37^{* *}$ & $1.35^{* *}$ & $1.6^{* *}$ & $-0.11^{* *}$ & $-0.07^{* *}$ \\
Line 4 & $-2.05^{* *}$ & $-1.23^{* *}$ & $-2.46^{* *}$ & $-1.36^{* *}$ & $-0.41^{* *}$ & -0.14 & $-0.05^{* *}$ & $-0.04^{* *}$ \\
Line 5 & $-4.1^{* *}$ & $-3.04^{* *}$ & $-2.17^{* *}$ & $-1.87^{* *}$ & $1.93^{* *}$ & $1.17^{* *}$ & $-0.17^{* *}$ & $-0.09^{* *}$ \\
L.S.D.05 (gi) & 0.25 & 0.199 & 0.165 & 0.244 & 0.27 & 0.259 & 0.011 & 0.011 \\
L.S.D.01 (gi) & 0.331 & 0.263 & 0.219 & 0.323 & 0.357 & 0.343 & 0.014 & 0.015 \\
\hline
\end{tabular}

* and ** significant at 0.05 and 0.01 levels of probability, respectively.

\section{b- Agronomic characters}

The best parents for plant height were Line 1,

Line 2, Line 3 and Line 5 corresponding with significant negative GCA effects. In addition, Giza 171, Misr 2 and Line 4 had highly significant positive estimates under both conditions and could be used as good combiners for tallness plant. For grain yield and its components, the best parents were Giza 171 and Misr 2 since their GCA were significant and positive under both conditions. In addition, significant positive GCA were showed by Line1 for SP and GY; Sids12 for KS; and Line 4 and Line 5 for KW. These results indicated that the best combiners are superior genotypes for improving agronomic characters, as shown in Table (9).

Table 9. Estimates of general combining ability effects of the parents for plant height and grain yield plant1 and yield components under optimum (SD1) and late sowing (SD2) dates.

\begin{tabular}{|c|c|c|c|c|c|c|c|c|c|c|}
\hline \multirow[t]{2}{*}{ Parents } & \multicolumn{2}{|c|}{$\begin{array}{c}\text { Plant height } \\
\text { (Ph) }\end{array}$} & \multicolumn{2}{|c|}{$\begin{array}{l}\text { No. of spikes } \\
\text { plant }^{-1} \text { (SP) }\end{array}$} & \multicolumn{2}{|c|}{$\begin{array}{l}\text { No. of kernels } \\
\text { Spike }^{-1}(\mathrm{KS})\end{array}$} & \multicolumn{2}{|c|}{$\begin{array}{c}\text { 100-kernel } \\
\text { weight }(\mathrm{KW})\end{array}$} & \multicolumn{2}{|c|}{$\begin{array}{c}\text { Grain yield } \\
\text { plant }^{-1}(\mathbf{G Y} / \mathbf{P})\end{array}$} \\
\hline & SD1 & SD2 & SD1 & SD2 & SD1 & SD2 & SD1 & SD2 & SD1 & SD2 \\
\hline & $3.08 * *$ & & $1.74 * *$ & $0.71 * *$ & $3.66^{* *}$ & $1.84^{* *}$ & $0.2 * *$ & & $7.71^{* * *}$ & $3.03 * *$ \\
\hline & & & 100 & -4.19 & & 147 & & & -0.34 & $-1.31 * *$ \\
\hline & & & & & & & & & $6.58 * *$ & $4.48^{* *}$ \\
\hline & & & & 1.34 & & & & & $.89 * *$ & $2.45 * *$ \\
\hline & & & & & & & & & $-3.08 * *$ & $-1.73 * *$ \\
\hline & & -2.87 & -0.7 & -0 . & & -7.1 & & & $-4.6 * *$ & $-2.27 * *$ \\
\hline & & & & & & -5.9 & & & -2.6 & $-1.59 * *$ \\
\hline & & $-2.37 * *$ & -1.8 & -0.8 & & -9.0 & $7 *$ & & $-7.56 * *$ & $-3.06 * *$ \\
\hline & & & & & & & & & & 0.474 \\
\hline & & & & & & & & & & 0.627 \\
\hline & & & & & & & & & & 0.716 \\
\hline L.S.D .01(gi-gj) & 1.566 & 1.479 & 0.89 & 0.722 & 2.275 & 2.021 & 0.123 & 0.112 & 1.078 & 0.947 \\
\hline
\end{tabular}

* and ** significant at 0.05 and 0.01 levels of probability, respectively.

\section{3- Specific combining ability (SCA) effects} a- Earliness characters

Days to heading data (Table 10) showed eight and eight crosses possess desirable significant SCA effects under optimum and late sowing dates, respectively. The most superior crosses were Misr 2 x Line 3, Line 1 x Line 2 and Line 1 x Line 3 under both conditions. Eight and four crosses had significant or highly significant negative SCA effects for days to maturity under optimum and late sowing dates, in sequence and Misr $2 \times$ Line 5 was the best cross under both conditions. There were nine and four crosses possessed desirably significant SCA effect for grain filling period under optimum and late sowing dates, consecutively, and the most superior crosses were Giza 171 x Line 5, Misr $2 \times$ Line 5 and Line $2 \times$ Line 3 . Significant positive SCA effects were detected in seven and nine crosses for grain filling rate under optimum and late sowing dates, sequentially and best crosses under both conditions were Sids $12 \times$ Line 3 , Sids $12 \times$ Line 4 and Line $1 \times$ Line 5 . Generally, the most superior and desirable crosses for most earliness characters at optimum sowing date were Sids $12 \mathrm{x}$ Line 5, Misr 2 x Line 2, Misr 2 x Line 3 and Line 1 x Line 2. For late sowing date the best crosses were Giza171 x Line4 and Misr2 $x$ Line3. For both sowing dates the most superior cross was Line1 $\mathrm{x}$ Line 2 . The most previously defined crosses possessed non-additive gene effects in different earliness characters and could be useful in wheat breeding programs for improving these characters. These results in harmony with obtained by Aglan (2009), and Akbar et al. (2009). 
Table 10. Estimates of specific combining ability effects for F1 crosses for days to heading and maturity and grain filling period and rate under optimum (SD1) and late (SD2) sowing dates.

\begin{tabular}{|c|c|c|c|c|c|c|c|c|}
\hline \multirow[t]{2}{*}{ Crosses } & \multicolumn{2}{|c|}{$\begin{array}{l}\text { Days to heading } \\
\text { (day) }\end{array}$} & \multicolumn{2}{|c|}{$\begin{array}{l}\text { Days to maturity } \\
\text { (day) }\end{array}$} & \multicolumn{2}{|c|}{$\begin{array}{c}\text { Grain filling period } \\
\text { (day) }\end{array}$} & \multicolumn{2}{|c|}{$\begin{array}{l}\text { Grain filling rate } \\
\left.\text { (g plant }^{-1} \text { day }^{-1}\right)\end{array}$} \\
\hline & SD1 & SD2 & SD1 & SD2 & SD1 & SD2 & SD1 & SD2 \\
\hline Giza $171 \times$ Sids 12 & -0.29 & 0.16 & 0.05 & -0.28 & 0.34 & -0.44 & $-0.1^{* *}$ & -0.02 \\
\hline Giza 171 × Misr 2 & 0.37 & 0.15 & $-0.84 * *$ & $1.73 * *$ & $-1.21 * *$ & $1.58 * *$ & $-0.07 * *$ & 0.03 \\
\hline Giza $171 \times$ Line 1 & -0.04 & $-0.63 *$ & $-2.11 * *$ & 0.32 & $-2.07 * *$ & $0.95 *$ & $-0.04 *$ & $0.11 * *$ \\
\hline Giza $171 \times$ Line 2 & 0.4 & 0.04 & -0.41 & -0.08 & -0.81 & -0.11 & 0.03 & -0.03 \\
\hline Giza $171 \times$ Line 3 & $-1.1 * *$ & -0.35 & $1.23 * *$ & -0.18 & $2.33 * *$ & 0.17 & -0.02 & $-0.04 *$ \\
\hline Giza $171 \times$ Line 4 & 0.71 & $-1.66^{* *}$ & $1.41 * *$ & $-0.86^{*}$ & 0.7 & $0.8^{*}$ & $0.05 * *$ & 0.03 \\
\hline Giza $171 \times$ Line 5 & $2.13^{* *}$ & $0.84 * *$ & 0.41 & -0.2 & $-1.72 * *$ & $-1.03 *$ & $-0.15 * *$ & -0.03 \\
\hline Sids $12 \times$ Misr 2 & $1.23 * *$ & -0.02 & $-1.24 * *$ & -0.31 & $-2.47 * *$ & -0.29 & $0.18^{* *}$ & -0.03 \\
\hline Sids $12 \times$ Line 1 & $2.01 * *$ & $-0.82 * *$ & $0.69 * *$ & -0.14 & $-1.32 * *$ & 0.67 & $-0.13 * *$ & $-0.04 *$ \\
\hline Sids $12 \times$ Line 2 & 0.4 & $-0.79 *$ & $1.1 * *$ & $1.47 * *$ & 0.7 & $2.27 * *$ & $-0.04 *$ & -0.01 \\
\hline Sids $12 \times$ Line 3 & $-0.77 *$ & -0.25 & $0.57 *$ & -0.06 & $1.35 * *$ & 0.19 & $0.07 * *$ & $0.21 * *$ \\
\hline Sids $12 \times$ Line 4 & $0.85^{*}$ & -0.21 & 0.37 & -0.27 & -0.48 & -0.06 & $0.13 * *$ & $0.04 *$ \\
\hline Sids $12 \times$ Line 5 & $-1.35 * *$ & -0.49 & $-1.09 * *$ & 0.64 & 0.26 & $1.13 * *$ & $-0.06 * *$ & -0.01 \\
\hline Misr $2 \times$ Line 1 & -0.69 & 0.07 & 0.04 & $-2.18 * *$ & 0.73 & $-2.26 * *$ & $0.1 * *$ & 0 \\
\hline Misr $2 \times$ Line 2 & $-0.77 *$ & 0.18 & 0.31 & -0.41 & $1.09 *$ & -0.59 & 0.02 & $0.05 * *$ \\
\hline Misr $2 \times$ Line 3 & $-1.04 * *$ & $-0.84 * *$ & 0.4 & $-1.18 * *$ & $1.43 * *$ & -0.34 & $-0.04 * *$ & $0.12 * *$ \\
\hline Misr $2 \times$ Line 4 & $1.39 * *$ & -0.26 & 0.17 & 0.31 & $-1.22 * *$ & 0.57 & -0.02 & 0.03 \\
\hline Misr $2 \times$ Line 5 & 0.43 & $1.0 * *$ & $-0.53 *$ & $-0.93 *$ & $-0.96 *$ & $-1.94 * *$ & $-0.04 *$ & $0.04 *$ \\
\hline Line $1 \times$ Line 2 & $-1.09 * *$ & $-0.77 *$ & $-0.84 * *$ & -0.47 & 0.25 & 0.3 & $-0.04 * *$ & -0.02 \\
\hline Line $1 \times$ Line 3 & $-1.38 * *$ & $-1.4 * *$ & 0.49 & -0.5 & $1.87 * *$ & $0.9 *$ & $-0.07 * *$ & 0.02 \\
\hline Line $1 \times$ Line 4 & 0.12 & -0.11 & $-0.53^{*}$ & 0.64 & -0.64 & 0.75 & -0.03 & -0.01 \\
\hline Line $1 \times$ Line 5 & -0.52 & $-1.37 * *$ & $-0.7 * *$ & 0.09 & -0.18 & $1.46 * *$ & $0.06 * *$ & $0.06^{* *}$ \\
\hline Line $2 \times$ Line 3 & $1.0^{*}$ & $0.89 * *$ & 0.01 & -0.19 & $-0.99 *$ & $-1.09 * *$ & 0.02 & $-0.04 *$ \\
\hline Line $2 \times$ Line 4 & $-0.77 *$ & $1.15 * *$ & $1.63 * *$ & 0.55 & $2.4^{* *}$ & -0.6 & $-0.06^{* *}$ & $0.05^{* *}$ \\
\hline Line $2 \times$ Line 5 & -0.25 & -0.2 & 0.22 & -0.39 & 0.47 & -0.18 & 0.01 & $0.04 *$ \\
\hline Line $3 \times$ Line 4 & $0.82 *$ & $0.78^{*}$ & 0.4 & $0.85^{*}$ & -0.42 & 0.06 & $0.08^{* *}$ & $-0.04 *$ \\
\hline Line $3 \times$ Line 5 & $1.45 * *$ & $1.03 * *$ & $0.54 *$ & $1.08 * *$ & $-0.9 *$ & 0.04 & -0.03 & -0.01 \\
\hline Line $4 \times$ Line 5 & 0.21 & 0.45 & -0.01 & 0.59 & -0.22 & 0.14 & -0.01 & 0 \\
\hline L.S.D.05(sij) & 0.77 & 0.61 & 0.51 & 0.75 & 0.83 & 0.79 & 0.03 & 0.04 \\
\hline L.S.D.01(sij) & 1.02 & 0.81 & 0.67 & 0.99 & 1.09 & 1.05 & 0.04 & 0.05 \\
\hline
\end{tabular}

* and ** significant at 0.05 and 0.01 levels of probability, respectively.

\section{b- Agronomic characters}

For plant height data (Table 11), three and three crosses possess desirable significant SCA effect under optimum and late sowing dates, respectively and Giza $171 \times$ Line 3 and Line $3 \times$ Line 5 were the most superior crosses under both conditions. Four and three crosses had significant positive SCA effects for number of spikes plant ${ }^{-1}$ under optimum and late sowing dates, respectively and Sids $12 \times$ Line 3 and Line $4 \times$ Line 5 were the best crosses under both conditions. There were five and seven crosses possessed desirably significant SCA effect for number of kernels spike ${ }^{-1}$ under optimum and late sowing dates, respectively, and the most superior crosses were Sids $12 \mathrm{x}$ Line 2, Sids $12 \mathrm{x}$ Line4 and Line $3 \times$ Line 5. Significant positive SCA effects were detected in nine and nine crosses for 100 kernel weight under optimum, and late sowing dates, respectively, and best crosses under conditions were Sids $12 \times$ Line 2, Sids $12 \times$ Line 5, Line $1 \times$ Line 3, Line $2 \times$ Line 3 and Line $4 \times$ Line 5. SCA effects were significant and positive in eight and twelve crosses for grain yield plant ${ }^{-1}$ under optimum and late sowing dates, respectively and best crosses under both conditions were Giza 171 x Line 4, Sids 12 x Line 3, Sids 12 x Line 4, Misr 2 x Line 2 and Line 1 x Line 5.

\section{D- Heterosis percentages}

From the breeder's point of view, positive percentages of heterosis would be of interest in most characters under investigation, however, for days to heading and maturity and plant height characters significant negative percentages would be useful.

\section{1- Earliness characters}

Significant negative heterotic effects over better parent for days to heading (Table 12) were recorded for 22 and 22 crosses and ranged from -1.64 to $-12.14 \%$ for Giza $171 \times$ Misr 2 and Line $1 \times$ Line 2 and from -1.36 to $-12.35 \%$ for Line $2 \times$ Line 4 and Line $1 \times$ Line 5 under optimum and late sowing dates, respectively. Days to maturity showed significant negative heterotic effects for 23 and 18 crosses and ranged from -0.64 to $-7.10 \%$; for Line $4 \times$ Line5 and Line $1 \times$ Line 2 and from 1.00 to $-5.43 \%$; for Giza171× Sids 12 and Misr $2 \times$ Line 5 under optimum and late sowing dates, respectively. Desirable negative and significant heterotic effects over better parent for grain filling period were observed in 14 and 16 crosses and differed from -3.79 to $-10.65 \%$ for Giza $171 \times$ Sids 12 , Line $1 \times$ Line 4 and Misr $2 \times$ Line 5 and from -2.76 to $-13.55 \%$ for Line $2 \times$ line 3 and Misr $2 \times$ Line1 under optimum and late sowing dates, respectively. Significant negative heterotic effects over better parent belonged to four and seven crosses and ranged from 7.04 to $34.56 \%$ for Sids $12 \times$ Misr 2 and Sids $12 \times$ Line 4 and from 7.56 to $40.04 \%$ for Misr $2 \times$ Line 1 and Sids $12 \times$ line 3. As e results of using early genotypes, Aglan (2009), and Akbar et al. (2009) obtained useful values of heterosis for earliness characters.

The degree of heterosis varied from cross to cross for earliness characters under optimum and late sowing dates, suggesting that the nature of gene action varied with the genetic architecture of the parents. In general, better parent heterosis effects were negatively significant for most crosses derived from the early parents under the two sowing dates. 
Table 11. Estimates of specific combining ability effects of $F 1$ crosses for plant height and grain yield plant ${ }^{-1}$ and yield components under optimum (SD1) and late sowing (SD2) dates.

\begin{tabular}{|c|c|c|c|c|c|c|c|c|c|c|}
\hline \multirow[t]{2}{*}{ Crosses } & \multicolumn{2}{|c|}{$\begin{array}{l}\text { Plant height } \\
\text { (Ph) }\end{array}$} & \multicolumn{2}{|c|}{$\begin{array}{l}\text { No. of spikes } \\
\text { plant }^{-1} \text { (SP) }\end{array}$} & \multicolumn{2}{|c|}{$\begin{array}{l}\text { No. of kernels } \\
\text { spike }^{-1}(\mathrm{KS})\end{array}$} & \multicolumn{2}{|c|}{$\begin{array}{l}100 \text { kernel weight } \\
(\mathrm{KW})\end{array}$} & \multicolumn{2}{|c|}{$\begin{array}{c}\text { Grain yield } \\
\text { plant }^{-1} \text { (GY/P) }\end{array}$} \\
\hline & SD1 & SD2 & SD1 & SD2 & SD1 & SD2 & SD1 & SD2 & SD1 & SD2 \\
\hline Giza $171 \times$ Sids 12 & -1.91 & 0.34 & -0.39 & 0.45 & $5.76^{* *}$ & 2.47 & -0.1 & -0.08 & $-4.79 * *$ & -1.31 \\
\hline Giza $171 \times$ Misr 2 & -1.24 & -1.61 & $-1.4 *$ & 0.54 & 2.79 & $3.64 *$ & -0.09 & 0.08 & $-5.3 * *$ & $2.57 * *$ \\
\hline iza $171 \times$ Line 1 & -0.2 & -0.21 & $-1.51 *$ & 0.15 & -1.16 & 2.77 & 0.04 & $0.2 *$ & $-4.61 * *$ & $5.03 * *$ \\
\hline za $171 \times$ Line 2 & 0.53 & $3.51 * *$ & -0.57 & $-1.48 * *$ & -2.68 & -0.62 & $0.2 *$ & & 0.94 & -1.07 \\
\hline $1 \times$ Line 3 & $-3.83 * *$ & $-3.61 * *$ & 1.17 & -0.07 & -1.43 & -0.04 & 0.02 & & 1.24 & -1.18 \\
\hline$\times \operatorname{Lin}$ & -1.94 & 1.01 & -0.44 & & 5 & 0.46 & -0.03 & & $2.9 * *$ & $1.91 *$ \\
\hline Line & 2.05 & $3.39 * *$ & -0.56 & -0.11 & -3.5 & -2.42 & $0.23 *$ & & $8.47 * *$ & $-1.99 * *$ \\
\hline Misr & 1.16 & -1.36 & $2.91 *$ & -0 . & -7.27 & 0.25 & $-0.4 * *$ & * & $6.89^{\prime}$ & $-1.46^{*}$ \\
\hline ne 1 & -1.05 & $-2.96^{*}$ & -0.52 & -0.73 & $-8.74 * *$ & $-4.4 * *$ & $-0.35^{* *}$ & $-0.18^{*}$ & $-7.5 * *$ & -1.27 \\
\hline ne 2 & $-2.82 *$ & -0.74 & $-4.62 * *$ & $-3.59 * *$ & $11.41 * *$ & $8.21 * *$ & $59 * *$ & $0.47 * *$ & -1.44 & 0.64 \\
\hline 3 & 1.57 & $3.39 * *$ & $4.33 * *$ & $4.14 * *$ & 2.49 & $-4.82 * *$ & -0.16 & 0.15 & $4.46 * *$ & $9.48 * *$ \\
\hline e 4 & 1.21 & -0.99 & -0.13 & -0.59 & $11.65 * *$ & $6.87 * *$ & $-0.23 *$ & 0.07 & $6.28 * *$ & $1.75^{*}$ \\
\hline & $3.7 * *$ & $5.64 * *$ & $-1.39 *$ & $-1.31 *$ & -2.85 & -0.61 & $0.27 * *$ & $0.31 * *$ & $-3.06 * *$ & 0.19 \\
\hline & 54 & $3.84 * *$ & $-1.86 * *$ & $-2.79 * *$ & 2.34 & $3.58 *$ & -0.03 & 0.13 & $5.48 * *$ & $-2.13 * *$ \\
\hline & .23 & 1.31 & $2.44 * *$ & 0.98 & $6.08 * *$ & -0.84 & 0.12 & 0.1 & $2.33 * *$ & $2.09 * *$ \\
\hline & $16^{* *}$ & 1.19 & $-2.71 * *$ & -0.4 & -0.59 & $3.19 *$ & 0.19 & 0.08 & -0.84 & $5.43 * *$ \\
\hline & 05 & 0.81 & $-2.23 * *$ & -1.02 & -2.6 & -3.09 & $31 * *$ & 01 & $-2.07 *$ & $1.51 *$ \\
\hline & 04 & -0.56 & -0.4 & -1.04 & -0.66 & $-5 * *$ & 0.17 & *** & $-2.3 * *$ & 0.29 \\
\hline & $5.18 * *$ & 0.21 & 0.29 & 0.04 & -1.91 & -2.04 & 0.15 & & $-1.82 *$ & -0.46 \\
\hline & 0.2 & $4.34 * *$ & 0.68 & 1.02 & 3.2 & -0.14 & $0.47 * *$ & $0.25 * *$ & $-1.75^{*}$ & $2 * *$ \\
\hline & 84 & & -1.29 & $-1.69 * *$ & 1.86 & $3.76^{*}$ & 13 & & $-1.94 *$ & 0.04 \\
\hline & $4.83 * *$ & $2.59 *$ & 34 & $86^{* *}$ & -0.08 & 2.08 & & & $3.83 * *$ & $4.28 * *$ \\
\hline & & & 0.36 & .72 & $-3.99 *$ & & $0.23 *$ & & 0.04 & $-2.64 * *$ \\
\hline & .18 & & -0.64 & & -3.01 & & 0.04 & & -1.41 & $1.67 *$ \\
\hline & & $3.31 * *$ & 0.43 & 0.96 & $-11.04 * *$ & $-3.75^{*}$ & $.2 *$ & & 0.49 & $1.59 *$ \\
\hline & $3.21 * *$ & 1.31 & -0.6 & -0.3 & -2.1 & -1.89 & 0.12 & & $3.62 * *$ & $-1.64 *$ \\
\hline & $-4.39 * *$ & $-5.06^{* *}$ & -0.7 & -0.94 & $3.56^{*}$ & $3.67 *$ & & $-0.24 * *$ & $-2.55 * *$ & -0.49 \\
\hline & 0.34 & & $1.44 *$ & $1.88^{* *}$ & -4.3 & -2.88 & $0.47 * *$ & $0.41 * *$ & -0.46 & 0.22 \\
\hline & & & & & & & & & 1.652 & 1.452 \\
\hline L.S.D.01(sij) & 3.175 & 2.999 & 1.804 & 1.464 & 4.613 & 4.099 & 0.249 & 0.226 & 2.186 & 1.921 \\
\hline
\end{tabular}

* and ** significant at 0.05 and 0.01 levels of probability, respectively.

Table 12. Estimation of heterosis over better parent for F1 crosses for days to heading and maturity and grain filling period and rate under optimum (SD1) and late (SD2) sowing dates .

\begin{tabular}{|c|c|c|c|c|c|c|c|c|}
\hline \multirow{2}{*}{ Crosses } & \multicolumn{2}{|c|}{ Days to heading (day) } & \multicolumn{2}{|c|}{ Days to maturity (day) } & \multicolumn{2}{|c|}{ Grain filling period (day) } & \multicolumn{2}{|c|}{ Grain filling rate (g plant $^{-1}$ day $^{-1}$ ) } \\
\hline & SD1 & SD2 & SD1 & SD2 & SD1 & SD2 & SD1 & SD2 \\
\hline Giza $171 \times$ Sids 12 & $-1.92 * *$ & $-3.01 * *$ & $-0.78 * *$ & $-1 *$ & $-3.79 * *$ & 1.2 & $-34.09 * *$ & $-13.31 * *$ \\
\hline Giza 171 × Misr 2 & $-1.64 * *$ & -0.27 & $-2.27 * *$ & -0.58 & $-6.28 * *$ & -1.52 & $-18.38 * *$ & $8.92 * *$ \\
\hline Giza $171 \times$ Line 1 & $-4 * *$ & $-5.06 * *$ & $-3.88 * *$ & -0.48 & $-8.36 * *$ & 0.75 & $-19.85 * *$ & $17.34 * *$ \\
\hline Giza $171 \times$ Line 2 & $-6.16^{* *}$ & $-8.14^{* *}$ & $-4.6 * *$ & $-2.94 * *$ & -1.76 & $-5.3 * *$ & $-27.47 * *$ & $-17.54 * *$ \\
\hline Giza $171 \times$ Line 3 & $-7.21 * *$ & $-7.99 * *$ & $-2.43 * *$ & $-2.46 * *$ & $4.93 * *$ & $-5.12 * *$ & $-34.71 * *$ & $-20.2 * *$ \\
\hline Giza $171 \times$ Line 4 & $-3.3 * *$ & $-7.47 * *$ & $-2.26 * *$ & $-2.98 * *$ & -0.34 & 1.85 & $-24.73 * *$ & $-7.82 *$ \\
\hline Giza $171 \times$ Line 5 & $-3.98 * *$ & $-6.68 * *$ & $-2.75 * *$ & $-2.86 * *$ & $-10.62 * *$ & $-7.21 * *$ & $-49.58 * *$ & $-21.48 * *$ \\
\hline Sids $12 \times$ Misr 2 & $-3.4 * *$ & $-2.61 * *$ & $-3.23 * *$ & $-3.07 * *$ & $-10.43 * *$ & $-3.93 * *$ & $7.04 * *$ & -5.01 \\
\hline Sids $12 \times$ Line 1 & $-4.53 * *$ & $-7.5 * *$ & $-2.71 * *$ & $-1.79 * *$ & $-8.69 * *$ & 0.06 & $-30.59 * *$ & $-14.24 * *$ \\
\hline Sids $12 \times$ Line 2 & $-3.64 * *$ & $-7.66 * *$ & $-2.64 * *$ & -0.54 & -1.01 & 1.45 & $-8.46^{*}$ & 4.04 \\
\hline Sids $12 \times$ Line 3 & $-4.38 * *$ & $-6.36 * *$ & $-1.96 * *$ & $-1.2 *$ & 2.02 & $-3.41 *$ & -0.44 & $40.04 * *$ \\
\hline Sids $12 \times$ Line 4 & $5.78 * *$ & $2.42 * *$ & $4.18 * *$ & $2.15 * *$ & 1.55 & 1.67 & $34.56 * *$ & $17.38 * *$ \\
\hline Sids $12 \times$ Line 5 & $-5.29 * *$ & $-6.74 * *$ & $-2.88 * *$ & $-1.03 *$ & $-4.4 * *$ & -0.89 & $-25.34 * *$ & 0.34 \\
\hline Misr $2 \times$ Line 1 & $-2.21 * *$ & $-3.89 * *$ & $-1.33 * *$ & $-3.73 * *$ & -1.6 & $-13.55 * *$ & $7.09 * *$ & $7.56^{*}$ \\
\hline Misr $2 \times$ Line 2 & $-10.11 * *$ & $-7.39 * *$ & $-5.6 * *$ & $-5.2 * *$ & 1.44 & $-4.95 * *$ & $-12.98 * *$ & 1.17 \\
\hline Misr $2 \times$ Line 3 & $-9.86 * *$ & $-7.97 * *$ & $-4.54 * *$ & $-5.23 * *$ & 1.71 & $-4.84 * *$ & $-23.58 * *$ & $8.14^{*}$ \\
\hline Misr $2 \times$ Line 4 & $-5.54 * *$ & $-5.23 * *$ & $-4.64 * *$ & $-4.08 * *$ & $-4.53 * *$ & -1.93 & $-15.05^{* *}$ & 0.77 \\
\hline Misr $2 \times$ Line 5 & $-8.6 * *$ & $-5.88 * *$ & $-4.92 * *$ & $-5.43 * *$ & $-10.65 * *$ & $-7.78 * *$ & $-29.12 * *$ & -4.37 \\
\hline Line $1 \times$ Line 2 & $-12.14 * *$ & $-12.19 * *$ & $-7.1 * *$ & $-4.13 * *$ & -0.63 & $-7.79 * *$ & $-26.85 * *$ & $-15.54 * *$ \\
\hline Line $1 \times$ Line 3 & $-11.91 * *$ & $-12.31 * *$ & $-5.21 * *$ & $-3.6 * *$ & 2.15 & $-6.92 * *$ & $-32.91 * *$ & $-11.9 * *$ \\
\hline Line $1 \times$ Line 4 & $-8.64 * *$ & $-8.91 * *$ & $-5.84 * *$ & $-2.69 * *$ & $-3.79 * *$ & -1.96 & $-23.6 * *$ & $-11.52 * *$ \\
\hline Line $1 \times$ Line 5 & $-11.29 * *$ & $-12.35 * *$ & $-5.76 * *$ & $-3.52 * *$ & $-9.63 * *$ & $-5.27 * *$ & $-26.38 * *$ & $-8.19 *$ \\
\hline Line $2 \times$ Line 3 & -0.03 & 0.43 & 0.26 & -0.83 & 0.72 & $-2.76 *$ & $-8.12 *$ & -6.99 \\
\hline Line $2 \times$ Line 4 & $-1.76 *$ & $-1.36 *$ & $1.33 * *$ & 0.61 & $6.24 * *$ & $-4.56 * *$ & $-9.45 *$ & $12.67 * *$ \\
\hline Line $2 \times$ Line 5 & -0.62 & -0.03 & $-1.62 * *$ & -0.14 & $-4.76 * *$ & -0.88 & $-18.2 * *$ & 5.32 \\
\hline Line $3 \times$ Line 4 & 0.78 & -1.16 & $1.53 * *$ & 0.64 & 0.28 & $-3.58 * *$ & $12.39 * *$ & -4.2 \\
\hline Line $3 \times$ Line 5 & 0.88 & 1.23 & -0.29 & 0.41 & $-5.47 * *$ & -0.86 & $-14.63 * *$ & 9.95 \\
\hline Line $4 \times$ Line 5 & -0.23 & $-1.69 * *$ & $-0.64 *$ & 0.83 & $-7.36 * *$ & $-2.92 *$ & $-9.98 *$ & 0.7 \\
\hline L.S.D.05(sij) & 1.196 & 0.951 & 0.790 & 1.167 & 0.052 & 0.055 & 1.289 & 1.239 \\
\hline L.S.D.01(sij) & 1.582 & 1.258 & 1.045 & 1.544 & 0.069 & 0.072 & 1.705 & 1.639 \\
\hline
\end{tabular}

* and ** significant at 0.05 and 0.01 levels of probability, respectively. 
As observed in the present study several workers have also reported the presence of considerable heterosis in wheat for earliness characters (Pansuriya, 2013).

\section{2- Agronomic characters}

The heterotic effects over better parent (Table 13) for the number of spikes plant ${ }^{-1}$ showed no significant positive values for any cross. Moreover, Only Sids 12 x Line 4 had significant positive heterotic effects for number of kernels spike $^{-1}$ and had values of 59.0 and $54.1 \%$ under optimum and late sowing dates, respectively, in addition Giza $171 \mathrm{x}$ Line 1 had significant positive heterotic effects with value of $7.9 \%$ in the late sowing date. Negative and significant heterotic effects of plant height were recorded for 10 and 10 crosses and ranged from -3.75 to $-11.11 \%$ for Sids $12 \times$ Line 2 and Giza $171 \times$ Line 3 and from -3.53 to $-8.64 \%$ for
Misr $2 \times$ Line 1 and Giza $171 \times$ Line 3 under optimum and late sowing dates, respectively. For 100 kernel weight the data showed significant positive heterotic effects for 10 and 10 crosses and ranged from 6.0 to $17.62 \%$ for Sids $12 \mathrm{x}$ Line 5 and Line $2 \times$ Line 3 and from 5.9 to $16.63 \%$ for and Giza $171 \times$ Line 1 and Sids $12 \times$ Line 2 under optimum and late sowing dates, respectively. Desirable positive and significant heterotic effects over better parent for grain yield plant $^{-1}$ were observed in three and nine crosses ranged from 7.5 to $36.8 \%$ for Misr $2 \times$ Line1 and Sids $12 \times$ Line 4 and from 7.9 to $52.46 \%$ for Line $1 \times$ Line 5 and Sids $12 \times$ line 3 under optimum and late sowing, respectively. Desirable significant heterotic effects for plant height, grain yield plant $^{-1}$ and yield components were also reported by Pansuriya (2013).

Table 13. Estimation of heterosis over better parent for $F 1$ crosses for plant height and grain yield plant ${ }^{-1}$ and yield components under optimum (SD1) and late sowing (SD2) dates.

\begin{tabular}{|c|c|c|c|c|c|c|c|c|c|c|}
\hline \multirow[t]{2}{*}{ Crosses } & \multicolumn{2}{|c|}{$\begin{array}{c}\text { Plant height } \\
\text { (PH) }\end{array}$} & \multicolumn{2}{|c|}{$\begin{array}{l}\text { No. of spikes } \\
\text { plant }^{-1} \text { (SP) }\end{array}$} & \multicolumn{2}{|c|}{$\begin{array}{l}\text { No. of kernels } \\
\text { spike }^{-1} \text { (KS) }\end{array}$} & \multicolumn{2}{|c|}{$\begin{array}{c}100 \text { kernel } \\
\text { weight }(\mathrm{KW})\end{array}$} & \multicolumn{2}{|c|}{$\begin{array}{c}\text { Grain yield } \\
\text { plant }^{-1} \text { (GY/P) }\end{array}$} \\
\hline & SD1 & SD2 & SD1 & SD2 & SD1 & SD2 & SD1 & SD2 & SD1 & SD2 \\
\hline Giza171 × Sids 12 & $-8.3 * *$ & -2.47 & $-37.39 * *$ & $-27.58 * *$ & -3.85 & $-6.79 * *$ & -2.59 & -1.25 & $-33.25 * *$ & $-10.6^{* *}$ \\
\hline Giza $171 \times$ Misr 2 & -1.11 & -2.35 & $-19.62 * *$ & $-15.34 * *$ & 2.21 & -2.79 & $-9.26 * *$ & -1.51 & $-23.5 * *$ & $14.9 * *$ \\
\hline $11 \times \mathrm{J}$ ine 1 & $-8.89 * *$ & $-5.43 * *$ & $-15.49 * *$ & -7.95 & $-7.57 *$ & $7.85^{*}$ & -2.86 & $5.9^{*}$ & $-26.54 * *$ & $18.58 * *$ \\
\hline $1 \times$ Line 2 & $-7.78 * *$ & -1.23 & $-17.79 * *$ & $-14.48 * *$ & $-13.33 * *$ & -5.6 & 0.23 & 3.0 & $-28.71 * *$ & $-11.14 * *$ \\
\hline $71 \times$ Line 3 & $-11.11 * *$ & $-8.64 * *$ & $-13.5 * *$ & -7.66 & $-11.57 * *$ & $-8.4^{*}$ & -5.53 & 1.79 & $-30.55 * *$ & $-13.03 *$ \\
\hline & & 0 & -16. & -6.59 & $-14.08 * *$ & -6 & 3.71 & 2.11 & $-25 * *$ & -2.1 \\
\hline & & -1.23 & & & & $-14.56 * *$ & $8.48 * *$ & $7.75 * *$ & $-49.81 * *$ & $-17.64 * *$ \\
\hline & -2.67 & $-6.12 * *$ & & $-39.05 * *$ & & -1.85 & $-18.45^{* *}$ & -4.95 & 3.91 & $-8.77 * *$ \\
\hline & & $-4.05 *$ & -36.4 & -37.7 & $-20.61 * *$ & $-14.45 * *$ & $-13.71 * *$ & & $-29.82 * *$ & -4.05 \\
\hline & -3.7 & -1.08 & -54.6 & -54.2 & $-6.61 * *$ & -7.53 & 4.66 & $16.63 * *$ & $-9.35 * *$ & 7.55 \\
\hline & & & & & & -23.9 & $-12.19 * *$ & & & $52.46 * *$ \\
\hline & & -1. & -34.2 & -33.6 & $59.04 * *$ & 54.07 & -1.09 & 0.46 & & $19.39 * *$ \\
\hline & 3.7 & $5.95 * *$ & -29.8 & -29.9 & $-21.88 * *$ & $-21.53 * *$ & $6^{*}$ & $8.26^{* *}$ & $-24.51 * *$ & $10.31 *$ \\
\hline & $* *$ & $-3.53 *$ & -22.3 & -26.85 & -3.88 & -3.33 & 1.2 & 5.2 & $7.54 * *$ & -0.03 \\
\hline & $44 * *$ & $-5.41 * *$ & $-12.53 * *$ & $-15.82 * *$ & -3.87 & $-15.48 * *$ & $10.75 * *$ & $11.99 * *$ & $-10.02 * *$ & 0.07 \\
\hline & -1.11 & $-5.88 * *$ & $-33 * *$ & $-23.28 * *$ & $-10.73 * *$ & $-13.75 * *$ & $9.65 * *$ & $7.39 *$ & $-18.95 * *$ & $7.98 *$ \\
\hline & & -2.35 & $-28.52 * *$ & -24.63 & $-16.01 * *$ & $-19.66 * *$ & 2.29 & -4.77 & $-17.51 * *$ & -1.17 \\
\hline & $-4.44 * *$ & $-7.06 * *$ & $-28.48 * *$ & $-28.82 * *$ & $-15.16 * *$ & $-25.49 * *$ & 5.32 & 3.6 & $-27.4 * *$ & $-8.76^{* *}$ \\
\hline & $5=1 * *$ & & $-11.62^{*}$ & $-11.33^{*}$ & $-9.56 * *$ & $-7.58 *$ & $9.9 * *$ & $9.63 * *$ & $-24.32 * *$ & -2.83 \\
\hline & 0 & $5.63 * *$ & $-13.08 * *$ & -8.15 & -2.94 & $-8.52 *$ & $14.59 * *$ & $9.25^{* *}$ & -27.01 & 3.21 \\
\hline & & & -18.2 & $-20.56 * *$ & -8.0 & & & & -23.64 & -0.8 \\
\hline & & $8.19 * *$ & -14.6 & -7.3 & -11.7 & $-8.1 *$ & 8.6 & 1.24 & $-22.11 * *$ & $7.94^{*}$ \\
\hline & & & & -15.3 & -8.2 & -0.3 & $7.62 * *$ & $15.48^{*}$ & -5.35 & $-8.7 *$ \\
\hline & & & -13 & -6.2 & $-10.73 * *$ & 2.76 & 0.9 & 2.76 & -3.83 & $10.4^{*}$ \\
\hline & 5 & 7.14 & -12 & -9.58 & $-22.92 * *$ & $-11.33 * *$ & $10.2 * *$ & & $-12.41 * *$ & 4.48 \\
\hline & & -1.04 & $-16.46^{* *}$ & -8.13 & -6 & -1.36 & 0.21 & $-7.15^{*}$ & $15.6^{* *}$ & 1.67 \\
\hline & -3.16 & $-4.23 *$ & -2.82 & -1.94 & -2.61 & 2.06 & 0.79 & $-6.59 *$ & $-18.02 * *$ & $10.48 *$ \\
\hline & & -1.04 & $-11.44^{*}$ & 1.31 & $-17 * *$ & -7.55 & $17.18^{* *}$ & $13.84 * *$ & -5.99 & 6.07 \\
\hline & & 3.536 & 2.126 & 1.726 & 5.438 & 4.832 & 0.293 & 0.267 & 2.577 & 2.264 \\
\hline L.S.D.01(sij) & 4.952 & 4.678 & 2.813 & 2.284 & 7.194 & 6.393 & 0.388 & 0.353 & 3.409 & 2.995 \\
\hline
\end{tabular}

$*$ and ** significant at 0.05 and 0.01 levels of probability, respectively.

\section{ACKNOWLEDGMENT}

Also, I want to extend my deepest gratitude and acknowledge the financial help offered to complete this work by Bill and Melinda Gates foundation through "Enhancing Food Security in Arab Countries Project".

\section{REFERENCES}

Abd El-Hamid, E. A. M. (2013). Genetic analysis of some bread wheat crosses under normal and water stress conditions. Egypt. J. Plant Breed 17:(2) 2013 Special Issue
Abdallah. E; M. M. A. Ali; M. A. T. Yasin and A.H. Salem (2015). Combining ability and mode of gene action for earliness, yield and some yield attributes of bread wheat (Triticum aestivum L.) genotypes grown on different sowing dates. Egypt. Zagazig J. Agric. Res., Vol. 42 No. (2).

Aglan, M. A. A. (2009). Breeding studies on earliness in wheat. Ph. D. Thesis, Minufiya Univ. Egypt.

Aglan, M.A. (2013). Genetic analysis of earliness, yield and yield components in some bread wheat crosses under two sowing dates. Egypt. J. Plant Breed. 17:(2) 2013 Special Issue 
Akbar, M.A.; J. Anwar; M. Hassain; M.H. Qureshi and S. Khan (2009). Line $x$ tester analysis in bread wheat (Triticum aestivum L.). J. Agric. Res., 47(1): 411-419.

Baker, R.J. 1978. Issues in diallel analysis. Crop Sci. 18:533-536.

El-Marakby,A.A Mohamed, Afaf M. Tolba and S.H. Saleh. (2007). Correlation and path coefficient analysis for some traits in diallel crosses of bread wheat under different environments. Egypt. J. Plant Breed.

EL-Saadoown A. W.; A. A. EL Hosery; S.A. Sedhom; M. EL. M. El-Badawy and A.A.A. ELHosary. (2017). Genetic analysis of aiallel arosses an aheat under stress and normal irrigation treatments. Egyptian J. of Plant Breeding (The 11th International plant Breading Conference 17-18 October 2017)

EXCEL (2016). Microsoft EXCEL Computer User's Guide. Griffing B (1956). A generalised treatment of the use of diallel crosses in quantitative inheritance. Heredity 10: 31-50.

Hammad, S.M. and M.S.M. Abd El -Aty (2007). Diallel analysis of genetic variation for earliness and yield and its components in bread wheat. J. Agric . Res. Kafer El-Sheikh Univ., 33 (1) : 88-100.

Hei. N; S. Hussein and M. Laing (2016). Heterosis and combining ability analysis of slow rusting stem rust resistance and yield and related traits in bread wheat. J. Euphytica. 207:501-514.

Jatav, S. K.; B.R. Baraiya and V.S. Kandalkar (2017). Combining ability for grain yield and its components different environments in wheat. Int. J. Curr. Microbiol.App.Sci. 6(8): 2827-2834

Kaur. P; and S. K. Mondal (2016). Combining ability for yield and its components in durum wheat (Triticum durum DESF.). over different sowing times. J. the biocan. 11(3):1937-1940.

Mahar, A. R.; P. A. Hollington; D. S. Virk and J. R. Witcombe (2003). Selection for early heading and salt-tolerance in bread wheat. Cereal Research Communications. 31(1/2): 81-88

Menshawy, A.M.M. (2004). Genetical analysis of grain yield and related traits in bread wheat. Egypt. J. Agric. Res., 82(1): 203-214.
Menshawy, A.M.M. (2005). Genetic analysis for earliness components in some wheat genotypes of different photothermal response. Egypt. J. Plant Breed., 9: 31-47.

Menshawy, A.M.M. (2007). Evaluation of some early bread wheat genotypes under different sowing dates : 1 . Earliness characters. Egypt J. Plant Breed., 11 (1) : $25-40$.

Moshref, M.K.H. (2006). Heterosis and combining ability in some bread wheat crosses. J. Agric., Mansuoura Univ., 31(3): 1213-1220.

Mousa, A. M. (2005). Nature and magnitude of genetic variance components in some hexaploid wheat crosses. Minufiya J. Agric. Res. Vol. 30 (2): 979-987.

Moussa, A.M. and A.A. Morad (2009). Estimation of combining ability for yield and its components in bread wheat( Triticum aestivum L.) using line $\mathrm{x}$ tester analysis. Minufiya J. Agric. Res., 34(3):1191-1205.

Naseem. Z; S. A. Masood; S. Irshad; N. Annum; M.K. Bashir; R. Anum; A. Qurban; A. Arfan; K. Naila and H. K. Nazar (2015). Critical study of gene action and combining ability for varietal development in wheat: An Overview. J. Life Sci. 12(3s):104-108.

Pansuriya, A. G. (2013). Genetic architecture of grain yield and its components in bread wheat (Triticum aestivum 1.) under different dates of sowing. $\mathrm{Ph}$. $\mathrm{D}$. Thesis, Junagadh Univ. India.

Ram. M; R. M. Singh and R. K. Agrawal (2014). Genetic analysis for terminal heat stress in bread wheat (Triticum aestivum L. EM Thell). J. the biocan. 9(2): 771-776.

Salem, Nagwa. R.A. and S.M. Abdel Dayem. (2006). Genetical study on some bread wheat crosses. J. Agric. Sci. Mansoura Univ., 31(8): 4873-4883.

Snedecor, G.W. and W.G. Cochran (1980). Statistical Methods. Seventh Edition. Iowa State University Press, Ames. Iowa, USA

Steel, R.G.D. and J.H. Torrie, (1980). Principle and Procedures of Statistics: A Biochemical Approach. 2nd Ed., McGraw-Hill Book Company Inc., New York, USA.

Wynne, J.C.; T.A. Emery and P.W. Rice (1970). Combining ability in arachis hypogeae II .Field performance of F1 hybrids crop. SCI.10:713-715.

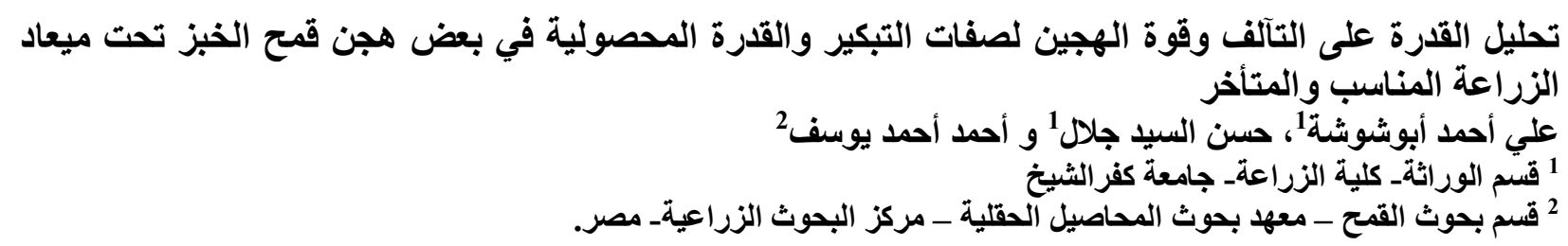

أجريت هذة الدر اسة في المزرعة البحثية بمحطة البحوث الزراعية بسخا كفر الثيخ مصر فى موسميى 2015/2014 و 2016/2015. وقد أستخدمت ثلاثة أصناف

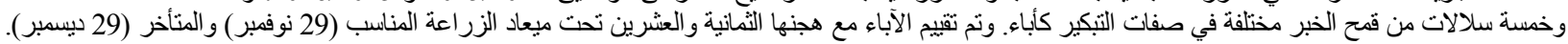

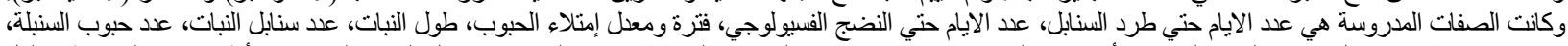

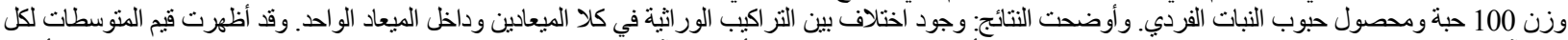

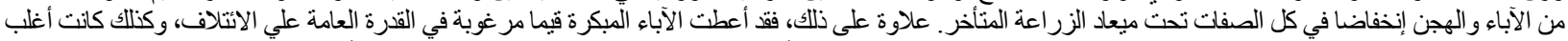

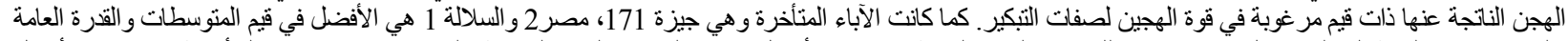

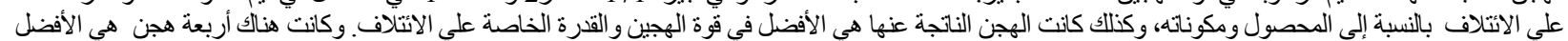

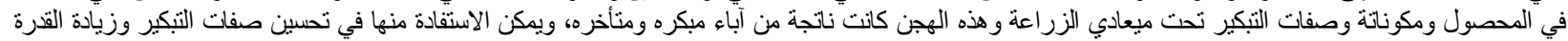

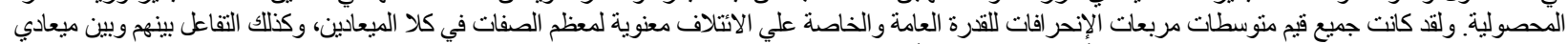

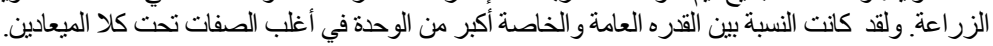

